\title{
VOLATILE COMPOUNDS FROM Rosmarinus officinalis L. AND Baccharis dracunculifolia DC. GROWING IN SOUTHEAST COAST OF BRAZIL
}

\author{
Yilan Fung Boix \\ Centro Nacional de Electromagnetismo Aplicado, Universidad de Oriente, Av. Las Américas, s/n, 5322 646378, Cuba \\ Cristiane Pimentel Victório* e Celso Luiz Salgueiro Lage \\ Instituto de Biofísica Carlos Chagas Filho, Universidade Federal do Rio de Janeiro, Av. Carlos Chagas Filho, s/n, CCS, Bloco G, \\ 21941-902 Rio de Janeiro - RJ, Brasil

\section{Ricardo Machado Kuster} \\ Núcleo de Pesquisas de Produtos Naturais, Universidade Federal do Rio de Janeiro, Av. Carlos Chagas Filho, s/n, CCS, Bloco H, \\ 21941-902 Rio de Janeiro - RJ, Brasil
}

Recebido em 4/12/08; aceito em 29/7/09; publicado na web em 11/1/10

\begin{abstract}
Chemical composition of leaf volatiles of Rosmarinus officinalis and Baccharis dracunculifolia cultured in Southeast of Brazil has been characterized by GC/MS after simultaneous distillation-extraction. The main components in volatiles of these species showed in common $\alpha$-pinene, myrcene, 1,8 cineole and camphor. Camphor was the major component among volatiles of $B$. dracunculifolia and $R$. officinalis with concentrations exceeding $25 \%$. B. dracunculifolia volatiles possessed more sesquiterpenes (21.4\%) than $R$. officinalis $(16.7 \%)$, such as caryophyllene (1.9\%) and $\alpha$-humulene $(0.4 \%)$. Lower concentrations of nerolidol and spathulenol were achieved in volatiles of $B$. dracunculifolia. Considering both species, there was a predominance of monoterpenes.
\end{abstract}

Keywords: rosemary; volatile compounds; simultaneous distillation-extraction.

\section{INTRODUCTION}

Baccharis species are in high concentration in Brazil comprising about 120 species described. ${ }^{1}$ In Brazilian traditional medicine is used for the treatment of physical tiredness, fever, hepatic alterations, gastric disorders and infections in digestive system. ${ }^{2}$ Baccharis dracunculifolia (Asteraceae) called alecrim in some parts of Brazil, or named vassoura, carqueja, green propolis, it is known as the most important source of Brazilian propolis that is extensively used to improve health and prevent diseases, and in beverages in various countries. ${ }^{2}$ In some Brazilian areas, folk people know this species as fake "alecrim". Brazil may be the center of origin of Baccharis genus also found in other places in South America. ${ }^{1}$ Studies about the chemical composition of the volatile compounds of $B$. dracunculifolia growing in different Brazilian regions have been described mainly in South Brazil, where its widely distributed, and in Southern regions. ${ }^{1,3}$

Rosmarinus officinalis (rosemary) from the Lamiaceae family, popularly known as alecrim in Brazil, is used for flavoring food and in traditional medicine to treat hepatic, intestinal, renal and respiratory affections. It is also known for its colagogue, antispasmodic activities and in stimulating the growth of hair. ${ }^{4}$ Demand for $R$. officinalis is increasing for its use in pharmaceutical industries and agribusiness. $R$. officinalis is an aromatic plant endogenous to Europe, Asia and Africa, mainly in areas surrounding the Mediterranean Sea. ${ }^{5}$ Volatile compounds of $R$. officinalis L. from different geographic origins have been performed and $\alpha$-pinene, 1,8 cineole, myrcene and camphor chemotypes have been identified. ${ }^{5,6}$ In Brazil, it has been reported cineole, pinene and cineole-pinene chemotypes from plant material collected in South Brazil. ${ }^{6,7}$ Although totally different botany family, $R$. officinalis and B. dracunculifolia plants present in common the folk use to treat wounds, hepatic disorders and close popular name. ${ }^{8}$

In the present study, we looked for a chemical similarity in the volatile compounds to agree with so close namely of these medicinal

*e-mail: cris.pvictor@gmail.com herbs by traditional cultures. The aim of this study was to investigate the chemical composition of $B$. dracunculifolia and $R$. officinalis volatiles comparing its components.

\section{EXPERIMENTAL}

\section{Plant material}

Baccharis dracunculifolia and Rosmarinus officinalis samples were collected in the morning, in September, in the city of Rio de Janeiro located in the tropical South Atlantic. Erika von Sohsten Medeiros and Gustavo Heiden (Rio de Janeiro Botanical Garden, Rio de Janeiro, Brazil) undertook the taxonomic identification of $R$. officinalis and $B$. dracunculifolia, respectively. Vouchers are deposited at the Herbarium of Rio de Janeiro Botanical Garden, under accession number RB 473641 (B. dracunculifolia) and RB 471608 (R. officinalis).

\section{SDE procedure}

Adult fresh leaves (5 g) of B. dracunculifolia and R. officinalis were homogenized with $70 \mathrm{~mL}$ of distilled water, placed in the sample flask, and submitted to simultaneous distillation-extraction (SDE) using SDE apparatus (Figure 1) as proposed by Godefroot. ${ }^{9}$ A $2 \mathrm{~mL}$ volume of dichloromethane was used as an organic collecting solvent, and placed in the solvent flask. Boiling chips were added to both flasks. Mineral oil bath under stirrer/heat plate was used to apply heat to flasks. The heating temperatures for the sample and solvent flasks were controlled to $110-130$ and $55-60{ }^{\circ} \mathrm{C}$, respectively, so that boiling in sample flasks began, and extraction was carried out for $2 \mathrm{~h}$. The vapors were condensed due to circulation of cooling water pumped to apparatus. SDE samples were introduced to the GC/FID and GC/MS for analysis.

\section{Volatile analysis}

Analytical GC/FID was carried out on a Varian Star 3400 gas 


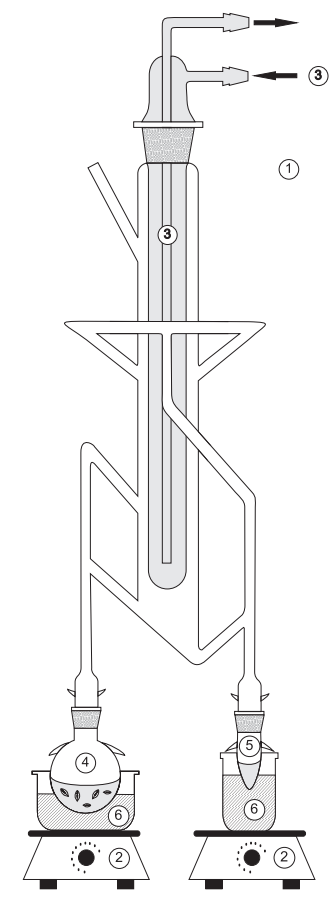

Figure 1. Schematic process of steam distillation-extraction. 1. steam distillation-extraction apparatus; 2. stirrer/heat plate; 3. cooling water; 4. sample flask ( $5 \mathrm{~g}$ fresh leaves $+70 \mathrm{~mL}$ water, heat plate: $\left.110-130{ }^{\circ} \mathrm{C}\right) ; 5$. solvent flask (2 $\mathrm{mL}$ dichloromethane, heat plate: $\left.55-60^{\circ} \mathrm{C}\right) ; 6$. mineral oil

chromatograph fitted with a DB-5/MS column $(30 \mathrm{~m} \times 0.25 \mathrm{~mm}$, film thickness $0.25 \mu \mathrm{m}$ ) and equipped with flame ionization detection (FID). Temperature was programmed from $60-290{ }^{\circ} \mathrm{C}$ at $5{ }^{\circ} \mathrm{C} / \mathrm{min}$. Sample injection of $1 \mu \mathrm{L}$ was performed at $270{ }^{\circ} \mathrm{C}$, splitless mode. Hydrogen was used as carrier gas, at linear velocity of $1 \mathrm{~mL} / \mathrm{min}$. Quantification was performed from GC/FID profiles using relative area (\%).

GC/MS analyses were performed using a Shimadzu Model GC MS-QP 2010 Plus apparatus under the following conditions: column, ZB-5MS fused silica capillary column $(30 \mathrm{~m}$ x $0.25 \mathrm{~mm}$, film thickness $0.25 \mu \mathrm{m}$ ); carrier gas, helium at $1 \mathrm{~mL} / \mathrm{min}$; injection of $1 \mu \mathrm{L}$; split ratio 1:40; injector temperature, $270{ }^{\circ} \mathrm{C}$; interface $230{ }^{\circ} \mathrm{C}$; column temperature, $60-290{ }^{\circ} \mathrm{C}$ at $5{ }^{\circ} \mathrm{C} / \mathrm{min}$; operating at $70 \mathrm{eV}$. Retention indices were calculated by van den Dool and Kratz method ${ }^{10}$ using retention times of $\mathrm{C}_{8}-\mathrm{C}_{28}$ that were injected after the volatile extracts at the same chromatographic conditions.

The linear retention indices for all compounds were determined by coinjection of a standard solution containing the homologous series of $n$-alkanes $\left(\mathrm{C}_{8}-\mathrm{C}_{28}\right)$. Individual constituents were identified by comparison of their mass spectra (MS) and retention indices (RI) with those reported in literature ${ }^{11}$ and also in National Institute of Standards and Technology (NIST) mass spectral database.

\section{RESULTS AND DISCUSSION}

The compounds identified by GC/MS for B. dracunculifolia and R. officinalis are listed in Table 1.

B. dracunculifolia showed light yellow volatile extract contains monoterpenes myrcene (10.2\%), 1,8 cineole (10.4\%), camphor $(25.2 \%)$ and verbenone $(10.1 \%)$ as the main compounds. High content of myrcene, cineole and camphor was the first time verified in volatile extracts obtained from B. dracunculifolia. Baccharis genus is characterized by the bitter taste due to sesquiterpenoid compounds. In current study, samples revealed lower sesquiterpene contents $(21.4 \%)$ in contrast with volatiles isolated from plant material collected in São Paulo (Southern of Brazil) that showed higher than $80 \%$ of sesquiterpenes among them nerolidol and spathulenol compared with total monoterpenes contents (14\%). ${ }^{3}$ Higher yield of nerolidol $(22.16 \%)$, the main constituent, and spathulenol (8.8\%) was also detected from samples collected in Rio Grande do Sul (South Brazil) and isolated through hydrodistillation, totalizing over $30 \%$ of leaf volatiles. ${ }^{12}$ Nerolidol and spathulenol, part of the oxygenated fraction, obtained from $B$. dracunculifolia volatile extracts have a high commercial value in perfumery industries. ${ }^{13} \mathrm{In}$ samples of B. dracunculifolia volatiles from Rio de Janeiro was not detected spathulenol and nerolidol, although these sesquiterpenes are typical in most $R$. officinalis plants, suggesting that these samples from Southeast coast of Brazil showed lower quality and are not accepted by pharmacopeias. ${ }^{1}$ A typical climate of Rio de Janeiro in September (19-24 ${ }^{\circ} \mathrm{C}, 64 \mathrm{~mm}$ rainfall), characterized by cool and dry winters, may contribute to these volatile profiles. In addition, a relationship between $B$. dracunculifolia volatiles variability and seasonal features was observed in samples of southern Brazil. ${ }^{3}$ The main sesquiterpene detected was caryophyllene (1.9\%). Low levels or lack of nerolidol and spathulenol are in agreement with other studies of B. dracunculifolia volatiles obtained from leaves collected in high altitude of the Atlantic Forest, São Paulo. ${ }^{13}$ In other studies on volatile composition of B. dracunculifolia from Bolivia samples, it was found high content of $\delta$-cadinene $(12.9 \%)$ and $\alpha$-muurolene $(3.16 \%){ }^{14}$

Studies have been demonstrated chemical variability in volatiles composition of $R$. officinalis from different geographic origins. The main chemotypes achieved to this species in relation to high content in volatiles has been $\alpha$-pinene, 1,8 cineole, myrcene and camphor..$^{5-7}$ In the present study, $R$. officinalis leaf volatiles were colorless and twentyfour constituents were characterized in samples from $R$. officinalis collected in Rio de Janeiro consisting in monoterpenes (75.0\%) and sesquiterpenes $(16.7 \%)$. The major components of the volatile extracts was $\beta$-pinene ( $7.0 \%)$, myrcene $(9.52 \%), 1,8$ cineole (14.02\%), camphor $(33.17 \%)$ and verbenone (8.6\%). Brazilian R. officinalis leaf volatiles of Southeast coast were of a camphor chemotype more similar to those of Tunisian regions due to their high amount of camphor. ${ }^{6}$ Samples of $R$. officinalis volatiles from South regions of Brazil, Rio Grande do $\mathrm{Sul}$, have been investigated and leaf volatiles revealed pronounced content of $\alpha$-pinene $(40.5 \% / 44.5 \%)$ and 1,8 cineole $(17.4 \% / 17.5 \%){ }^{7}$ Comparing volatiles isolated from $R$. officinalis cultured in different Brazilian regions, Southeast coast was the ones that induced high amount of camphor.

On the contrast $R$. officinalis leaf volatiles, the samples obtained from $B$. dracunculifolia besides caryophyllene also presented sesquiterpenes $\alpha$-humulene $(0.4 \%), \alpha$-muurolene $(0.14 \%), \delta$-cadinene $(0.17 \%)$ and caryophyllene oxide $(0.2 \%)$. The main differences in volatile composition consisted of $B$. dracunculifolia presented higher amount of sesquiterpenes compared with $R$. officinalis leaf volatiles, although in low amount. Comparing the major monoterpene constituents of leaf volatiles from B. dracunculifolia and $R$. officinalis, it was found similarity in quality and quantity considering $\alpha$-pinene, myrcene, 1,8 cineole and camphor. This similarity in volatiles composition may justify same aspects of the use of its species in Brazilian folk medicine and agreement with the close popular name - alecrim. Myrcene, 1,8 cineole and camphor have been reported to be involved in therapeutic use to treat digestive and hepatic disorders. According to Oliveira et al. ${ }^{15} \alpha$-myrcene presented inhibitor reversible effect of the monooxygenases hepatic enzymes, suggesting the interference in process of biotransformation of xenobiotic compounds. $\beta$-myrcene has proved to elevate the levels of apoproteins CYP-2B1 and CYP-2B2, which are subtypes of cytochrome $\mathrm{P} 450$ (CYP) enzyme system responsible for catalysing the oxidative metabolism of a wide variety of xenobiotic compounds. ${ }^{16}$ The monoterpene cineole is an anti-inflammatory considered a potential agent in the prevention of gastrointestinal inflam- 
mation and ulceration mainly to cause repletion of glutathione, central constituent of the antioxidant system required to maintain a healthy liver. ${ }^{17}$ Camphor has also been reported to induce enzymes such as glutathione S-transferase that contribute to detoxification of chemicals and drugs, and UDP-glucuronosyl-transferase in liver. ${ }^{18}$

In sum, the detection of the same proportion of myrcene, cineole and camphor in leaf volatiles of $B$. dracunculifolia and $R$. officinalis

Table 1. Volatile compounds (\%) of Baccharis dracunculifolia and Rosmarinus officinalis leaves

\begin{tabular}{|c|c|c|c|c|}
\hline \multirow{3}{*}{$\begin{array}{l}\text { Constituents }^{\mathrm{a}} \\
\alpha \text {-pinene }\end{array}$} & \multirow{2}{*}{\multicolumn{2}{|c|}{$\mathrm{RI}_{\text {calculated }}$}} & \multicolumn{2}{|c|}{ Relative Area ${ }^{c}$} \\
\hline & & & \multirow{2}{*}{$\begin{array}{c}\text { B. dracunculifolia } \\
\mathbf{4 . 8}\end{array}$} & \multirow{2}{*}{$\begin{array}{c}\text { R. officinalis } \\
9.5\end{array}$} \\
\hline & $936^{1}$ & $935^{2}$ & & \\
\hline$\alpha$-camphene & 954 & 951 & 1.7 & 4.0 \\
\hline verbenene & - & 953 & - & 0.1 \\
\hline thuja-2,4(10)-diene & 957 & - & 0.2 & - \\
\hline$\beta$-pinene & 981 & 978 & 1.5 & 7.0 \\
\hline myrcene & 989 & 988 & 10.2 & 9.5 \\
\hline$\alpha$-phellandrene & 1008 & 1003 & 0.22 & 0.2 \\
\hline$\alpha$-terpinene & 1018 & 1015 & 0.4 & 0.6 \\
\hline$\rho$-cymene & 1027 & 1026 & 0.24 & 2.7 \\
\hline limonene & 1032 & - & 3.5 & - \\
\hline 1.8 cineol & 1037 & 1034 & 10.4 & 14.0 \\
\hline$\gamma$-terpinene & 1061 & 1057 & 1.7 & 1.9 \\
\hline p-mentha-2.4(8)-diene & - & 1082 & - & 0.8 \\
\hline terpinolene & 1087 & - & 1.1 & - \\
\hline linalool & 1100 & 1099 & 0.5 & 1.8 \\
\hline chrysanthenone & 1126 & 1122 & 0.32 & 0.4 \\
\hline camphor & 1149 & 1153 & 25.2 & 33.2 \\
\hline pinocarvone & - & 1162 & - & 0.54 \\
\hline menthol & - & 1171 & - & 1.15 \\
\hline borneol & 1177 & - & 2.1 & - \\
\hline terpinen-4-ol & 1184 & 1179 & 1.6 & 1.0 \\
\hline$\alpha$-terpineol & 1198 & 1194 & 3.33 & 2.1 \\
\hline verbenone & 1214 & 1208 & 10.1 & 8.6 \\
\hline n.i. ${ }^{\text {b }}$ & 1267 & 1266 & 0.17 & 0.2 \\
\hline n.i. ${ }^{b}$ & 1274 & - & 0.3 & - \\
\hline bornyl acetate & 1286 & 1280 & 0.6 & 1.1 \\
\hline cedrene & - & 1411 & - & 4.2 \\
\hline caryophyllene & 1422 & - & 1.9 & - \\
\hline santalene & - & 1447 & - & 0.8 \\
\hline$\alpha$-humulene & 1458 & - & 0.4 & - \\
\hline$\gamma$-muurolene & 1476 & - & 0.14 & - \\
\hline$\delta$-cadinene & 1519 & - & 0.17 & - \\
\hline caryophyllene oxide & 1586 & - & 0.2 & - \\
\hline epi- $\alpha$-bisabolol & 1687 & 1677 & 0.18 & 0.3 \\
\hline Monoterpenes & & & 78.5 & 75.0 \\
\hline Sesquiterpenes & & & 21.4 & 16.7 \\
\hline
\end{tabular}

${ }^{\mathrm{c}}$ Constituents were arranged in order to retention time on the ZB-5 column. ${ }^{\mathrm{b}}$ not identified. ${ }^{\mathrm{c}}$ Values were obtained in duplicate. ${ }^{1,2} \mathrm{RI}$ calculated: ${ }^{1} B$. dracunculifolia and ${ }^{2} R$. officinalis. $\mathrm{RI}=$ retention index. converges to the similar folk medicine use in hepatic diseases what suggests that these compounds may act synergistically. One other possibility is that the content of common terpenoids, in low concentration, achieved in both species may contribute to their therapeutic effects when the crude extract is used.

\section{ACKNOWLEDGMENT}

We thank the CAPES - Brazil/Cuba international program for its financial support throughout this work and for the fellowship of the first author. We also would like to acknowledge especially the MSc A. P. Esperanço who made schematic art.

\section{REFERENCES}

1. Fabiane, K. C.; Ferronatto, R.; Santo, A. C.; Onofre, S. B.; Rev. Bras. Farmacogn. 2008, 18,197.

2. Lorenzi, H.; Matos, F. J. A.; Plantas medicinais no Brasil: nativas $e$ exóticas, Nova Odessa, Instituto Plantarum: São Paulo, 2008; Budel, J. M.; Duarte, M. R.; Santos C. A. M.; Farago, P. V.; Acta Farm. Bonaerense 2004, 23, 477; Teixeira, E. W.; Negri, G.; Meira, R. M. S. A.; Message, D.; Salatino, A.; Advance Access Publication 2005, 6, 85; Abad M. J.; Bermejo, P.; ARKIVOC 2007, 7, 76; Oliveira, S. Q.; Dal-Pizzol, F.; Moreira, J. C. F.; Schenkel, E. P.; Gosmann, G.; Acta Farm. Bonaerense 2004, 23, 365 .

3. Queiroga, C. L.; Fukai, A.; Marsaioll, A. J.; J. Braz. Chem. Soc. 1990, 1, 105; Queiroga, C. L.; Bastos, J. K.; de Souza, J. P. B.; de Magalhães, P. M.; J. Ess. Oil Res. 2008, 20, 111; Frizzo, C. D.; Atti-Serafini, L.; Laguna, S. E.; Cassel, E.; Lorenzo, D.; Dellacassa, E.; Flav. Fragr. J. 2008, 23, 99.

4. Al-Sereiti, M. R.; Abu-Amer, K. M.; Sem, P.; Indian J. Exp. Biol. 1999, 37, 124; Tôrres, A. R.; Oliveira, R. A. G.; Diniz, M. F. F. M.; Araújo, E. C.; Rev. Bras. Farmacogn. 2005, 15, 373; Souza, C. R. F.; Schiavetto, I. A.; Thomazini, F. C. F.; Oliveira, W. P.; Braz. J. Chem. Eng. 2008, 25, 59.

5. Pintore, G.; Usai, M.; Bradesi, P.; Juliano, C.; Boatto, G.; Tomi, F.; Chessa, M.; Cerri, R.; Casanova, J.; Flav. Fragr. J. 2002, 7, 15.

6. Atti-Santos, A. C.; Rossato, M.; Pauletti, G. F.; Rota, L. D.; Rech, J. C.; Pansera, M. R.; Agostini, F.; Serafini, L. A.; Moyna, P.; Braz. Arch. Biol. Technol. 2005, 48, 1035; Miguel, M. G.; Guerreiro, C.; Rodrigues, H.; Brito, J.; Duarte, F.; Venâncio, F.; Tavares, R.; Proc. of the 3rd IASME/ WSEAS Int. Conf. on Energy, Environment, Ecosystems and Sustainable Development, Agios Nikolaos, Greece, 2007; Zaouali, Y.; Boussaid, M.; Biochem. Syst. Ecol. 2008, 36, 11.

7. Atti-Santos, A. C.; Agostini, F.; Pansera, M. R.; Rossato, M.; Atti-Serafini, L.; Rev. Bras. Farmacogn. 2004, 6, 44.

8. Freise, F. W.; Boletim de Agricultura 1933, 34, 252; Fenner, R.; Betti, A. W.; Mentz, L. A.; Rates, S. M. K.; Braz. J. Pharm. Sci. 2006, 42, 369.

9. Godefroot, M.; Sandra, P.; Verzele, M.; J. Chromatogr. 1981, 203, 322

10. van den Dool, H.; Kratz, P. D.; J. Chromatogr. 1963, 11, 463.

11. Adams, R. P.; Identification of Essential Oil Components by Gas Chromatography/Mass Spectroscopy, Allured: Carol Stream IL, 2001.

12. Schossler, P.; Schneider, G. L.; Wunsch, D.; Soares, G. L. G.; Zini, C. A.; J. Braz. Chem. Soc. 2009, 20, 277.

13. Verdi, L. G.; Brighente, I. M. C; Pizzolatti, M. G.; Quim. Nova 2005, 28, 85; Lago, J. H. G, Romoff, P.; Fávero, O. A.; Quim. Nova 2008, 31, 727.

14. Loayza, I.; Abujder, D.; Aranda, R.; Jakupovic, J.; Collin, G.; Deslaurier, H.; Jean, F. I.; Phytochemistry 1995, 48, 381.

15. Oliveira, A. C. A. X.; Ribeiro-Pinto, L. F.; Gonçalves, A.; Paumgartten, J.; Toxicol. Lett. 1997, 92, 39.

16. Oliveira, A. C. A. X.; Ribeiro-Pinto, L. F.; Otto, S.; Gonçalves, A.; Paumgartten, J.; Toxicology 1997, 124,135.

17. Santos, F. A.; Silva, R. M.; Campos, A. R.; de Araújo, R. P.; Lima Júnior, R. C. P.; Rao, V. S. N.; Food Chem. Toxicol. 2004, 42, 579.

18. Banerjee, S.; Welsch, C. W.; Rao, A. R.; Cancer Lett. 1995, 88, 163. 